\title{
Physical Performance of West Java Soccer Athletes during February to December 2012
}

\author{
Army Zaka Anwary ${ }^{1}$, Ambrosius Purba ${ }^{2}$, Tertianto Prabowo ${ }^{3}$ \\ ${ }^{1}$ Faculty of Medicine, Universitas Padjadjaran, ${ }^{2}$ Department of Physiology, Faculty of Medicine, \\ Universitas Padjadjaran, ${ }^{3}$ Department of Physical Medicine and Rehabilitation, Faculty of \\ Medicine, Universitas Padjadjaran/Dr. Hasan Sadikin General Hospital, Bandung
}

\begin{abstract}
Background: Soccer is one of the sports included in the 18th National Sports Week (Pekan Olahraga Nasional, (PON) 2012, in Riau. Soccer requires a good physical condition to perform various football techniques such as running, shooting, dribbling, tackling, sliding, throw-in and heading. A good physical component can be achieved through a well-rounded program in accordance to the periodization training program. This study was conducted to describe the physical performance of the West Java's football athletes in order to develop periodization training program and to predict the athletes' performance.

Methods: A descriptive study was carried out on 23 West Java's football athletes using secondary data from West Java's KONI sports medicine team test reports during the period of February to December 2012. The variables in this study were 7 predominant physical components in football as follows: muscle strength, muscle endurance, speed, agility, flexibility, explosive leg muscle power, and general endurance (VO2 max). All components were categorized asInsufficient, Fair, Good, Excellent, and Perfect compared to the central KONI standards.

Results: The leg muscle strength, abdominal muscle endurance, speed, agility of all athletes were not considered perfect. Not one of the components was above $50 \%$ which was the excellent category. Only Arm and shoulder endurance $(56.5 \%)$, speed $(68.18 \%)$, and leg muscle power $(52.17 \%)$ were in good category. The most of the results regarding the athletes' leg muscle strength was categorized as fair. All results in the abdominal endurance were in insufficient category.

Conclusion: Not all physical performance components are achieved perfectly by all of the football athletes.
\end{abstract}

Key words: Athletes, football, physical performance

\section{Introduction}

Football is a popular sport that competes in all around the world. Football has been played in China since 2nd century during the reign of the Han dynasty by Chinese soldiers. However, modern football and its rules are claimed and was formed in 1846 in Cambridge, England. ${ }^{1}$

Football is a sport that requires a good physical condition to perform a variety of football techniques such as running, shooting, dribbling, tackling, sliding, throwin and heading. By observing the athlete's movement patterns, we determined the predominant physical components that is important in achieving the maximum athlete's performance, which are: the leg muscle strength, arm and shoulder extensor muscle strength, arm and shoulder flexor muscle strength, leg muscle endurance, arm and shoulder muscle endurance, abdominal muscle endurance, speed, agility, flexibility, leg muscle power, and general endurance. ${ }^{2}$ A good physical component can be achieved through a well-rounded program in accordance to the periodization training program. ${ }^{3}$

In Indonesia, football is one of the contested sports at the National Sports Week/Pekan Olahraga Nasional (PON) 2012 held in province of Riau. In previous PON (East Kalimantan Province, 2008), West Java's football athletes failed in qualification rounds. Lack of physical traits is believed as the reason why the team

Correspondence: Army Zaka Anwary, Faculty of Medicine, Universitas Padjadjaran, Jalan Raya Bandung-Sumedang Km.21, Jatinangor, Sumedang, Indonesia, Phone: +628122028841 Email: armyzaka@gmail.com 
Table 1 Percentage of Physical Component Ability Category Football Athletes of West Java, Riau PON XVIII

\begin{tabular}{lccccc}
\hline \multirow{2}{*}{$\begin{array}{c}\text { Physical Component } \\
\text { Condition }\end{array}$} & \multicolumn{5}{c}{ Percentage } \\
\cline { 2 - 6 } & Insufficient & Fair & Good & Excellent & Perfect \\
\hline Muscle Strength: & & & & & \\
- Leg & $17.39 \%$ & $60.87 \%$ & $17.39 \%$ & $4.35 \%$ & $0.00 \%$ \\
- Arm \& Shoulder & $8.0 \%$ & $39.13 \%$ & $26.09 \%$ & $13.04 \%$ & $13.04 \%$ \\
Extensor & & & & & \\
- Arm And Shoulder & $17.39 \%$ & $26.09 \%$ & $34.78 \%$ & $17.39 \%$ & $4.35 \%$ \\
Flexor & & & & & \\
Muscle Endurance: & & & & & \\
- Leg & $0.00 \%$ & $9.09 \%$ & $22.73 \%$ & $22.73 \%$ & $45.45 \%$ \\
- Arm and Shoulder & $0.00 \%$ & $4.35 \%$ & $56.52 \%$ & $34.78 \%$ & $4.35 \%$ \\
- Abdominal & $100.00 \%$ & $0.00 \%$ & $0.00 \%$ & $0.00 \%$ & $0.00 \%$ \\
Speed & $4.55 \%$ & $27.27 \%$ & $68.18 \%$ & $0.00 \%$ & $0.00 \%$ \\
Agility & $52.17 \%$ & $43.48 \%$ & $0.00 \%$ & $4.35 \%$ & $0.00 \%$ \\
Flexibility & $0.00 \%$ & $4.76 \%$ & $14.29 \%$ & $33.33 \%$ & $47.62 \%$ \\
Leg Muscle Power & $0.00 \%$ & $13.04 \%$ & $52.17 \%$ & $30.44 \%$ & $4.35 \%$ \\
General Endurance & $17.39 \%$ & $26.09 \%$ & $34.78 \%$ & $17.39 \%$ & $4.35 \%$ \\
\hline
\end{tabular}

could not match upin that competition. In the year 2012, there will be another PON conducted in Riau. Based on previous PON experiences and the relatively short periode of the team formation, the exact condition of the athletes' physical performance should be measured in order to develop the periodization training program and to predict the athletes' performance at PON XVIII Riau. ${ }^{3}$

\section{Methods}

A descriptive study was carried out on 23 West Java's football athletes using secondary data from Komite Olahraga Nasional Indonesia (KONI)West Java branch sports medicine team test reports during the period of February to December 2012. The variables in this study were 7 predominant physical components in football as follows: muscle strength using a dynamometer, muscle endurance by squats-jump tests, push-ups and situps for 60 seconds, speed with a 50-meter run tests, agility by beam side step test, flexibility by flexometer, explosive leg muscle power by vertical jump test, and general endurance (VO2 max) by Astrand Rhyming test. All components were categorized into Insufficient, Fair, Good, Excellent, and Perfect compared to the central KONI standards.

\section{Results}

From table 1, all the athletes' leg muscle strength, abdominal muscle indurance, speed, agility were not considered perfect. Moreover, not one of the components were above $50 \%$, which were in excellent category. Only Arm and Shoulder endurance $(56,5 \%)$, speed $(68,18 \%)$, and leg muscle power $(52,17 \%)$ were in good category. The most results in athletes' leg muscle strength were in fair category. Hundred percent of the abdominal endurance was in insufficient category.

\section{Discussions}

An athlete must have a good physical condition to achieve the maximum performance., West Java's football athletes should have a maximum physical condition to obtain the gold medal at the PON XVIII Riau. ${ }^{5}$ The West Java's football athletes leg muscle strength measurements results show that most of the athletes are in fair category $(60.87 \%)$.

The maximum leg muscle strength ability is required by football athletes, especially to kick the ball optimally and increase the odds to score. However, based on the West Java coach interviews results, the athletes has not achieved the maximum exercises to improve 
muscle strength because they has not complete the strength training routine. According to the experts, muscle strength can be improved by doing a maximum of three sets of 8-12 reps weight training, and performed 2-3 times per weeks. $^{3}$

In addition, the leg muscle strength, the arm and shoulder extensor muscles strength are also needed to achieve maximum performance. The arms and shoulders extensor muscle strength measurements results showed that majority athletes are in fair category $(39.13 \%)$. In this case, an improvement in the arm and shoulder extensor muscles components are needed, because the arm and shoulder extensor muscles are the key to ensure the athletes' ability to survive an opponent's physical contact within the game. A routine muscle strength exercises will result in myofibril hypertrophy due to increased number and diameter of muscle fibers, and increased connective tissue and ligamen strength., 4,6

Combination of arm and shoulder extensor strength with arm and shoulder flexor muscles strength play an important role in football. The flexor muscles strength is needed to throw the ball. The arms and shoulders flexor muscle strength measurement results show that most athletes were in good category (34.78\%). The arms and shoulders flexor muscle strength of the West Java's football athletes must be maintained so that they can perform optimally.

The leg muscle endurance measurements results show that most of the West Java's football athletes are in the perfect category (45.45\%). Leg muscle endurance plays an important role in football because during the game, the leg muscles tend to contract continually either to run or to kick the ball. Majority athletes reach the perfect category, although they do not made centralized training.

Besides of leg muscle endurance, the arm and shoulder muscle endurance are other components of the physical condition that are necessary for the maximum the football performance. The arm and shoulder muscle endurance measurements results of show that the majority athletes are in good category $(56.52 \%)$ and no athletes are included in the insufficient category. This is consistent with field observations that West Java's football athletes have conducted programs to improve arm and shoulder muscle endurance corresponding to the periodization training program.

The athletes' abdominal muscle endurance need to be improved, because based on the measurement results, the West Java's football athletes' abdominal muscle endurance are all in insufficient category (100.00\%). To achieve an optimum performance, the abdominal muscular endurance component needs to be improved, because the abdominal muscles along with the leg, arm and shoulder muscles functione as the body balancer during dribbling movement, kicking, running, and other moves related to match training. According to expert opinions, muscular endurance can be increased by up to 20-25 reps, three sets of weight training, 2-3 times per weeks. ${ }^{3}$

The West Java's football athletes' speed measurements results showed that most athletes are in good category (68.18\%). There are not a single athlete reaches the perfect category, and it is because during the exercise, the athletes do not accelerate their running speed. So the athletes do not speed up their running capabilities. Since the speed plays an important role in a football game, this component is needed to be improved. Speed is needed as the ability to pursuit a ball or to run fast avoiding the opposing team defense. Speed capability can be improved by running as far as 40-60 m with increasing acceleration. ${ }^{3,7}$

The West Java's football athletes' agility measurementresultsshowed thatmostathletes are in insufficient category (52.17\%). Agility is one of the physical abilities components required by football athletes to perform various techniques with agile. However, the results showed that the athletes' agility is still in the insufficient category. This is consistent with field observations that training for agility is still well organized because the training is more focused on improving teamwork and tactics. According to experts, the agility can be improved with exercise the zigzag run, squatthrust, or steeplechase run.,8

The flexibility measurements results showed that the majority of West Java's football athletes are in the perfect category (47.62\%). The athletes' flexibility ability reach the optimum condition because of their regular flexibility exercises. This condition should be maintained with regular flexibility exercises, because if not, the flexibility can be reduced and cause the decrease of athletes' speed and agility. 3,8 With good flexibility skills, athletes can enhance the movement ability so they can play football in the field with agile. Flexibility can be maintained by practicing routine stretching. ${ }^{78}$ According to experts, stretching exercises that can increase the joint space to its maximum is a passive stretching or PNF (proprioceptive neuromuscular facilitation). ${ }^{3}$ 
The leg muscle power measurements results showed that most West Java's football athletes are in good category $(52.17 \%)$. The results showed good category and none are in insufficient category because of their proper and regular leg exercises. Even so, the athletes' leg muscle power still needs to be improved so that performance can be achieved more leverage. In order to increase the muscles power, a weight training with low to sub maximum intensity can be conducted under strict observation to strength and speed components. ${ }^{3,7}$ The combination of vertical jump exercises (pylometric exercises) accompanied by low-intensity weight training can increase the leg muscles power. $^{3}$ A pylometric training goal is to improve the muscle coordination. The weight training goal is to increase the muscle power itself.

The West Java's football athletes' general endurance (VO2 max) measurements results showed that the athletes are in good category (34.78\%). Even so, there are still some athletes who are in the insufficient category, because they are not doing a regular aerobic exercise. If a football athlete is lack of general endurance ability, he cannot maintain his best performance during 90 minutes match. With increasing the aerobic workout, will result the increase of blood pumping capability of the heart, so that oxygen-rich blood supply to the muscles will also increase and the athletes will be able to exercise longer without excessive fatigue. ${ }^{9,10}$

According to experts, exercises to improve general endurance are by doing aerobic exercise. Aerobic exercises that can increase general endurance are jogging, running, bike, and swimming. Exercises can be done as much as 3-5 times a week, for more than an hour, with 75-85\% maximum pulse intensity. 3,9

The limitation of this study is there was not enough samples because of limitation of the number of football athletes that were trained to participate to PON Riau.

The conclusion, not all of the physical performance components are achieved perfectly by all of the football athletes. Hence the description above, it is expected that West Java's football athletes of XVIII PON Riau can further enhance their athletes' general endurance so that they all can achieve a better category for achieving the maximum results.

\section{References}

1. Orejan J. Football/soccer: history and tactics.North Carolina: McFarland;2011.

2. Tim Sports Medicine. Prosedur dan instrumen evaluasi fungsional atlet, Standar KONI Pusat. Jakarta: KONI; 2011.

3. Bompa TO, Haff G. Periodization: theory and methodology of training. 5thed. Champaign: Human Kinetics; 2009.

4. American College of Sports Medicine. ACSM's Guidelines for exercise testing and prescription. 7th ed. Baltimore: Lippincott, Williams \& Wilkins; 2006.

5. Komite Olahraga Nasional IndonesiaBidang Sport Science dan Penerapan Iptek Olahraga. Pemahaman dasar sport science \& penerapan iptek olahraga. Jakarta: KONI; 2012.

6. Giriwijoyo YS, editor. Ilmu Faal Olahraga. 7th ed. Bandung: Rosda;2007.

7. McArdle WD. Energi nutrition and human performance. Baltimore. Maryland: Lipincott Williams \& Wilkins; 2010.

8. Purba A. Kardiovaskular dan faal olahraga. Bandung: Universitas Padjadjaran;2012.

9. Brooks G, Fahey T, Baldwin K. Exercise physiology: Human bioenergetics and its applications. New York: McGraw-Hill; 2005.

10. Guyton AC, Hall JE. Textbook of medical physiology, 11th ed. Philadelphia: Elsevier Saunders; 2006. 